\title{
"SOU SÓLIDO, E TENHO (OU SOU) UMA OBRA": HERBERTO HELDER E A AMBIC̣ÃO DE SER POEMA
}

\section{"I AM SOLID, AND I HAVE (OR AM) A WORK" HERBERTO HELDER AND THE AMBITION TO BE A POEM}

http://dx.doi.org/10.11606/issn.2175-3180.v12i22p22-46

Constance von Krüger de Alcântara e Silva ${ }^{\mathrm{I}}$

\section{RESUMO}

O presente artigo tem como objetivo apresentar uma hipótese acerca da autoria na poesia de Herberto Helder. A partir da leitura de alguns poemas e também de algumas de suas obras reflexivas em prosa, percebe-se a possibilidade de que a participação do poeta em seus poemas, embora não confessional, possua caráter biográfico. Ainda: a misantropia do poeta (em seu voto de silêncio iniciado em 1968) seria indício de seu desejo de dizer-se somente por meio de sua obra; um desejo de ser poema. A apreensão da poesia de Herberto Helder, nesse sentido, possibilitaria o vislumbre borrado de um autorretrato.

\section{PALAVRAS-CHAVE}

Poesia; Herberto Helder; Poesia portuguesa; Autor; Autorretrato.

\section{ABSTRACT}

This article aims to present a hypothesis about authorship in Herberto Helder's poetry. In some poems and also in some of his reflective works in prose, it is possible to perceive the possibility that the poet's participation in his poems, although non confessional, may have a biographical character. Besides that, the poet's misanthropy (in his vow of silence started in 1968) would be an indication of his desire to speak only through his work; a desire to be a poem. The apprehension of Herberto Helder's poetry, thereby, would show the blurred glimpse of a self-portrait.

\section{KEYWORDS}

Poetry; Herberto Helder; Portuguese poetry; Author; Self Portrait.

\footnotetext{
I Universidade Federal de Minas Gerais, Minas Gerais, Brasil.
} 
Não, não sei de cor as pequenas composições de palavras. Retenho a fantasia, a objectividade delas - ponto onde me apoio para saber que sou sólido, e tenho (ou sou) uma obra. (Herberto Helder, em "Vida e obra de um poeta")

Dizem: ele é uma palavra. E chega o verão, e eu sou exactamente uma Palavra. (Herberto Helder, em "As musas cegas")

No cenário da poesia portuguesa da segunda metade do século XX e do início do século XXI, Herberto Helder figura não só como grande expoente diante da crítica, da academia e do público, mas como o poeta que radicalizou o gesto de se entregar à obra para se dizer apenas e somente por meio dela. Misantropo de 1968 até 2015, ano de sua morte, Helder almejava escrever o poema de uma vida - plano que levou a cabo a partir da revisitação constante e da reescrita sistemática dos fragmentos que compõem o seu poema contínuo ${ }^{1}$. A ideia de um perene lapidar da obra poética se relaciona à perspectiva de uma escrita ininterrupta, que, por ser parte de um todo que se reinventa, não cessa de reverberar - o que explica em parte como, mesmo após a morte do autor, em 23 de março de 2015, a obra continue viva, pujante, extrema, imensa².

A busca de uma poesia lida sem o rosto de seu poeta em primeiro plano assinala a maneira peculiar de Herberto Helder se filiar à própria obra. Por meio do silêncio que o cercou como pessoa e da recusa da vida pública - que se concretizou a partir do voto de silêncio que fez em 1968, o autor se inscreveu em seus poemas, de modo que eles se aproximam do

\footnotetext{
${ }^{1}$ De acordo com o próprio poeta, sua vida foi marcada por um único poema contínuo: assim batizou a súmula publicada em 2001: Ou o poema contínuo.

${ }^{2}$ A obra mutante e perenemente recortada de Herberto Helder, ainda que com a morte do poeta ocorrida em 2015, não cessa de se transformar para um leitor situado em 2020; saíram publicados dois livros póstumos: Letra aberta (2016) e Em minúsculas (2018). A probabilidade de que novas publicações surjam existe, e, portanto, é infundada qualquer intenção de pesquisa que envolva uma noção de finitude de sua obra.
} 
poeta de forma autônoma e supostamente descolada de uma autobiografia, mas, ainda assim, marcados por sua assinatura peculiar.

A hipótese mais plausível sobre o primeiro recuo de Herberto Helder em relação a uma vida pública se apresenta a partir do gesto de censura em relação à obra Apresentação do rosto, justamente em 1968:

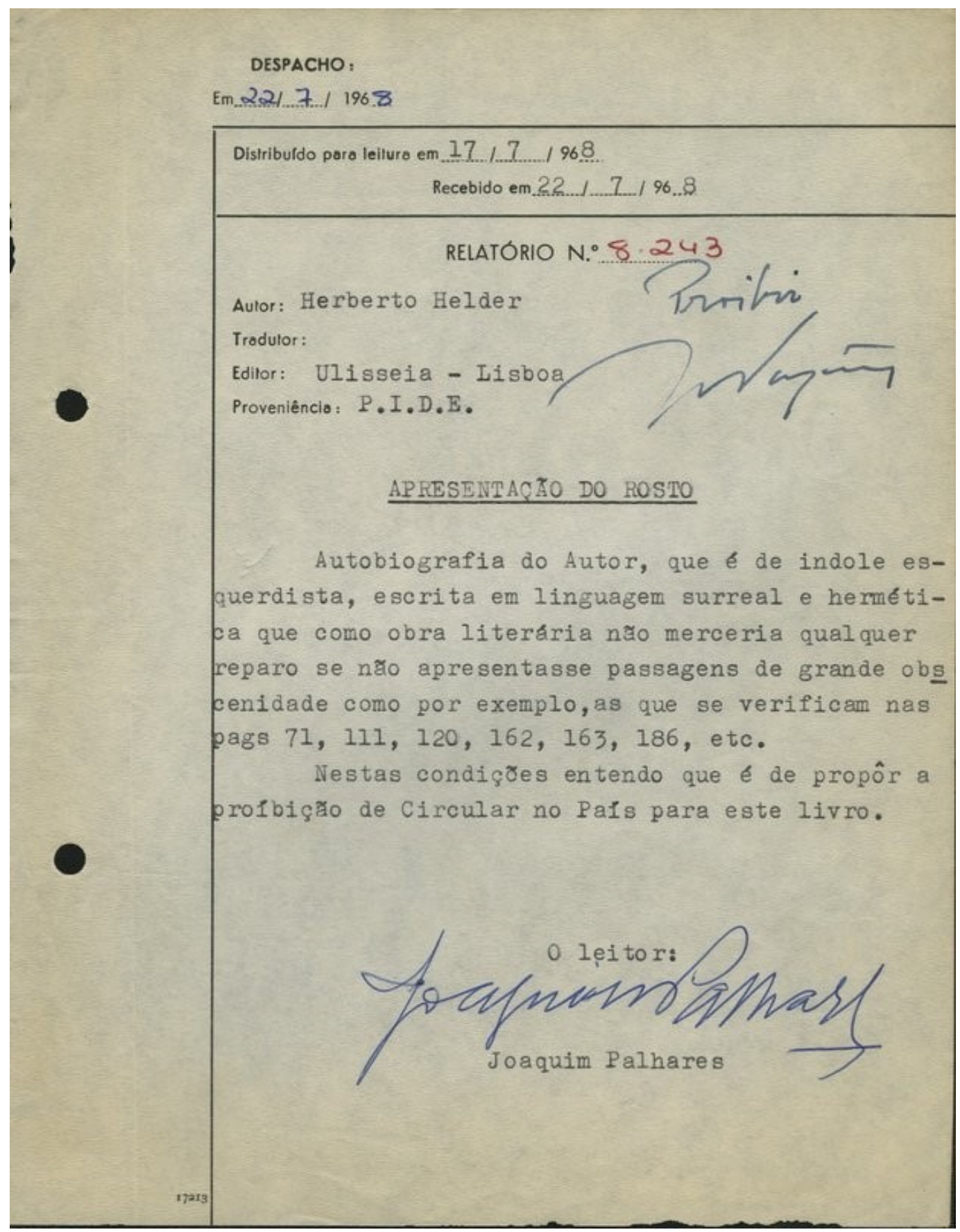

Figura 1 - Censura a Apresentação do rosto

Fonte: <https://bit.ly/2HlfL3k>. Acesso em: 7 dez. 2018 
Há, contudo, também, a fala do poeta em relação a esse gesto como uma espécie de conduta voluntária:

Estar-me-ia prometida a fremente cabeça de uma Diotima saída das fogueiras? Devo ainda falar e falar, depois de 1968, o ano em que finalmente! - me prometi ao silêncio? 1968 foi a minha melhor descoberta, e também um ano que me custou quase a respiração. Pois parece ser necessário que fale. Porque há a aposta, na apresentação tribal (digamos), na minha Diotima problemática. Estou lá, num buraco luminoso. Há ainda ao serviço da minha regeneração emblemática uma alta transparência, a manhã que me fornece uma espécie de fé conspiradora no corpo - ainda subalterno, mas fervoroso, tão paciente! Vejo-me fácil, conduzido a velozes cumplicidades com o mundo. Claro que esta facilidade era por si uma dificuldade, porque então: assim é que se ajusta contas com uma biografia?, uma biografia sobrecarregada? (HELDER, 2013, p. 42)

A querela que se estabelece em relação à participação autobiográfica de Herberto Helder em sua obra oferece alguns caminhos de pensamento. A noção de assinatura, por si só, é profícua quando se considera que esse gesto de assinar, de escrever o nome, é um ato que evoca uma ausência. Na impossibilidade de estar na obra, todo autor faz uma espécie de autocitação, uma referência ao seu nome, que, por sua vez, refere-se a si mesmo. Mas a assinatura pode também ser marca de um estilo - único e intransferível, por sua vez. Quem assina (e isso inclui uma noção de corporeidade viva, da mão física do artista) é quem é capaz de assumir a autoria do que produziu, ainda que o produto de sua criação seja descolado de sua vivência no mundo. Neste sentido, a relação do criador com sua obra se mostra vertiginosamente indissociável - em conformidade com o que assinala o crítico e também poeta Manuel Gusmão: “Um poeta fica no poema também pelo modo como dele se ausenta" (GUSMÃO, 1998, p. 5).

O nome próprio é alvo de investigações na Literatura - desde a questão do autor à questão da assinatura:

Michel Foucault defendeu em ensaio famoso que o nome de autor não funciona exatamente como os outros, afetado por oscilação entre o pólo da designação e o pólo da descrição mais perturbadora do que em qualquer outro nome próprio. (...) A conclusão de Foucault é que o nome de autor não se situa nem no registro civil nem na ficção, mas na 
ruptura que instaura certo tipo de discursos e a respectiva singularidade. A figura dessa ruptura é o que aqui chamo, na esteira de Derrida, assinatura. Assinar significa inscrever na obra o nome próprio - em princípio o nome civil, mas não necessariamente -, numa operação de eficácia dupla: por um lado, indicação e reivindicação de origem, de paternidade, de responsabilidade, por outro, possibilidade de curso próprio libertado da origem e fora do alcance da paternidade. A assinatura é sempre momento de despedida: o autor separa-se da obra, e a obra separa-se do autor, guardando dele apenas a memória, quer dizer, o nome. Assim, não é exatamente o nome próprio de autor que difere dos outros, mas a operação de assinatura que o cinde, permitindo-lhe continuar a designar um indivíduo, anterior à obra e seu primeiro agente, do memo passo que descreve já não o indivíduo, mas a obra: por efeito de assinatura, o nome converte-se em nome de obra, mais ainda, em nome de certa maneira, de certo estilo [...]. Mas essa eficácia da assinatura assenta na possibilidade essencial de todo o nome próprio: poder designar o portador na sua ausência, poder chamá-lo ou invocá-lo mesmo quando já não pode responder por ele mesmo quando está morto.

(...)

A assinatura é, por isso, a operação que consuma a morte do autor, do mesmo passo que lhe assegura a sobrevivência. (BAPTISTA, 2003, p. 10-11)

A eficácia da assinatura se mostra pluripotente: é a presença da filiação da obra, de quem a criou. Mas é também a marca da ausência desse criador, que se despediu deixando sua marca, selando como impossível o reencontro com uma obra que é agora do mundo. A assinatura, contudo, não é somente por vias da escrita do nome próprio. A maneira com que o autor pincela sua subjetividade em sua obra é também uma assinatura, a que se chama estilo.

Esse estilo, essa marca de presença-ausente de um autor, é o que discute o poeta no conto que leva esse nome (HELDER, 1980, p. 11-14), e é o primeiro da obra Os passos em volta (1980). Em "Estilo", Herberto Helder afirma, logo de início: "Se eu quisesse, enlouquecia. Sei uma quantidade de histórias terríveis", e, a partir desse imperativo, apresenta a vida como um "acontecimento excessivo". Por não aguentar a "desordem estuporada da vida", e de forma a evitar a loucura do contato absurdo com o real, há que se contar justamente com o estilo, que "é a maneira subtil de transferir a confusão e a violência da vida para o plano mental de uma unidade de significação". E mais: é forçoso, necessário, encontrar um estilo - "Procure 
o seu estilo, se não quer dar em pantanas" é o que se deveria pendurar em cartazes pelas cidades. Esse encontro é possível por meio de um exercício contínuo e diário. Como exemplo, o autor descreve o seu processo de esvaziar palavras, que consiste na repetição dessas unidades fundamentais (como Amor, Doença, Medo, Morte, Metamorfose) até que não signifiquem mais nada: o excesso, nesse caso, conduz ao nada. Segundo o poeta, é um dos meios que utiliza para alcançar o seu estilo³.

O gesto extremamente subjetivo de criação do estilo próprio se relaciona ao fazer poético de Herberto Helder, pois marca sua forma personalíssima de obter uma espécie de método, e que culmina na forma de sua poesia: autoral no sentido primeiro dessa palavra. A obra crítica de Herberto Helder pode, em uma hipótese sintética e redutora, dividir-se, por meio de um esforço analítico, em duas linhas. A primeira se relaciona a uma sorte de magia - em que se encontram obras que tratam da obscuridade do poeta, e de seu sagrado ${ }^{4}$. A segunda se atenta para a linguagem ${ }^{5}$, para o texto em si, para o método, e neste caso, trata justamente do estilo do autor - e da forma com que constrói suas imagens, por obscuras e mágicas que sejam. O recorte aqui proposto, por muito que evoque bibliograficamente variados aspectos sobre a obra helderiana, tem maior proximidade, em uma espécie de afinidade eletiva, com a segunda "linhagem", que se denomina, aqui, por "metatextual", em diferenciação à "magia" da primeira linhagem. A forma de fazer - como uma arquitetura do poema - é o que aqui interessa mais.

Em relação à perspectiva de vínculo entre autor e obra - e de um consequente entrelaçamento entre a vida do poeta e sua poesia, a pesquisadora Rosa Maria Martelo lança a hipótese de que o nome da súmula $\mathrm{Ou}$ o Poema Contínuo, lançada pela primeira vez em 2001, seria como a forma equivalente de se referir a Herberto Helder. A sugestão da autora é de que se escreva Herberto Helder ou o Poema Contínuo em uma relação de equivalência. De tal modo, ambos os nomes estariam em itálico, como em um título que antecipa como há alguma fusão entre quem escreve e o que escreve; entre arquiteto e arquitetura. Essa hipótese parte do pressuposto de que a conjunção ou, que tem função disjuntiva (alternativa),

\footnotetext{
3 Para Herberto Helder, "o estilo é a criação da dignidade" (HELDER, 2013, p. 54). Por essa razão, afasta-se, aqui, a possibilidade de leitura de uma proposição irônica acerca do estilo por parte do autor.

${ }^{4}$ Como, por exemplo, o trabalho de Maria Estela Guedes, em Herberto Helder, poeta obscuro.

${ }^{5}$ Como os trabalhos de Rosa Maria Martelo e Manuel Gusmão, por exemplo.
} 
nesse caso, é inclusiva. Não oferece alternância ou escolha, mas é aditiva, apresenta uma soma de ideias. É “uma pista, uma instrução de leitura que radicaliza o paradoxo de o esvaziamento de um nome no mundo pode levar à sua hipertrofia na obra - que afinal devolve ao mundo" (MARTELO, 2016, p. 13).

Essa possibilidade de equivalência dá a ver o crescimento de uma persona de Herberto Helder em sua própria poesia - que, afinal, é parte de si - e alcançada pelo esforço pessoal da criação de seu estilo. $O$ esvaziamento do "eu" no mundo (com o silêncio eleito como método, ou mesmo como ética) faz crescer o que de seu nome há em sua obra. Se há um crescimento do nome do poeta na obra (uma hipertrofia), parece ser paradoxal que haja uma diminuição do sujeito (um processo de dessubjetivação, ocasionado pelos silêncios do poeta), também no poema. Contudo - e em se tratando de Herberto Helder, em que o paradoxo é importante ferramenta - isso é possível por meio da emergência de imagens, em um processo de substituição do biográfico pelo poético. Como exemplo na própria poesia helderiana, pode-se citar a morte da mãe: por tantas vezes poeticamente apresentada, torna-se a versão definitiva do que se conhece. De maneira análoga, outros acontecimentos supostamente baseados na biografia de Herberto Helder se emancipam como imagens poéticas e assim ocupam o lugar de uma espécie de versão oficial de um texto biográfico que não se escreveu (como, por exemplo, a própria descrição da casa da infância do poeta). Para Gusmão (1998), as características que tornam o indivíduo único não se perdem no texto, antes se prestam a singularizar ainda mais a escrita. Esse acontecimento se explica por meio de um pacto firmado ao ler Helder: o que se escreve é autêntico por estar escrito, em um texto em que não importam categorias como 'histórico' ou 'factual'. A existência de uma verdade unívoca, inquestionável, é uma falácia que não encontra respaldo nem na Literatura, nem na História, quanto menos na Poesia, pois o gesto de "salvar" o passado encontra barreiras no próprio ato narrativo - o que se evidencia pela impossibilidade de a linguagem exercer domínio total sobre o vivido e reproduzi-lo ${ }^{6}$. Em Herberto Helder, especialmente, a "veracidade" não pode ser nem uma questão; afinal, é do mundo que o poeta parte, mas sua

\footnotetext{
${ }^{6}$ A linguagem não representa bloqueio total ao vivido, dado que a poesia não é desconectada da realidade. A linguagem, nesse sentido, é incapaz de representar a totalidade do real - não se desligando completamente dele, mas sendo, como toda e qualquer representação, uma falha. É nessa falha que habita a poesia.
} 
viagem, em forma de criação poética, transcende o conceito de representação do real. É, segundo ele mesmo, "o talento de saber tornar verdadeira a verdade" (HELDER, 2013, p. 55) O destino é, portanto, sistematicamente incerto, duvidoso.

\section{APRESENTAÇ̃̃O DO ROSTO: AUTORRETRATO}

O poeta, que submete sua biografia à poesia, tem seu nome descolado de sua vivência no mundo ${ }^{7}$ e inserido em uma realidade poética a partir de imagens que se formam por meio de sua escrita - e que são evidências, ou rastros, dessa participação do autor em sua obra. Nesse sentido, as imagens poéticas que emergem podem, então, ser a fronte que o poeta pretende tornar pública; podem, as imagens, funcionar como uma apresentação do rosto.

Essa expressão é o título de uma pintura de si mesmo, um autorretrato $^{8}$ pessoal e íntimo, tão somente revelado pela força da escrita do autor, que desvela, entre outras, algumas memórias de sua infância. Apresentação do rosto foi publicado em $1968^{\circ}$, ano de crucial importância em termos éticos, estéticos e políticos, sobretudo na Europa e nas Américas. Neste texto raro e precioso, do ponto de vista supostamente autobiográfico, Herberto Helder percorre caminhos demarcados pelas pegadas de si próprio em tempos idos, que se presentificam pela escrita. A forma de se apresentar está colada a uma formulação de uma espécie de memorial poético, em que habitam recordações que deixaram vestígios no

\footnotetext{
${ }^{7}$ O nome completo de batismo de Herberto Helder é: Herberto Helder Luís Bernardes de Oliveira. A cisão no nome para a publicação já é indício de como o poeta é um ser-outro do homem no mundo, elegendo justamente o duplo " $\mathrm{h}$ " - uma espécie de paradoxo, em que a letra muda se repete: dois silêncios ensurdecedores. É uma escolha de assinatura que reflete a presença-ausente do autor como o paradoxo que cultivou em toda a sua obra.

${ }^{8}$ Beaujour defende que um autorretrato não é uma autobiografia, pois prescinde de um caráter narrativo complexo: "L'autoportrait se distingue de l'autobiographie par l'absence d'un récit suivi" (BEAUJOUR, 1980, p. 8). O uso da palavra autorretrato, no contexto de Herberto Helder, relaciona-se com a noção de que as suas incursões autobiográficas se assemelham mais a imagens e menos a narrativas organizadas. Por velozes e em movimento que são, essas imagens não apresentam caráter linear.

${ }^{9}$ O Maio de 68 em Paris, a Primavera de Praga, a consolidação e o aprofundamento de regimes ditatoriais, como no Brasil, a morte de Martin Luther King e outros eventos sincrônicos redefiniram a maneira de estar no mundo em termos também culturais, e, nesse sentido, uma publicação literária datada de tal ano é de relevância para a compreensão do espírito dessa época. Em Portugal, Salazar é afastado, o que dá início ao processo de extinção do regime salazarista, que findaria em 1974.
} 
mundo real a que pertence o homem e que são alçadas ao patamar de linguagem pela palavra-magia do poeta.

Entretanto tal equação não se dá de maneira simples. De acordo com Paulo Braz (2015), a experiência de vida é excessiva, e fonte principal do ato de criação. Mas esse ato não transcreve a experiência à maneira da realidade. Sendo o poeta o "rival do mundo", ele absorve de sua experiência algo que recupera pela invenção, e que se dissolve, em partes, no contato com a memória. O poema é o apuramento e a intensificação da experiência ${ }^{10}$, e o que promove o trânsito entre o caos do mundo e alguma ordem, na linguagem. Surge, desse processo, uma imagem, que, por não ser mimética, é da ordem da transfiguração - termo imprescindível à poética helderiana. Na linguagem, a experiência se torna palpável, aí está a sua força reveladora. Algo de mistério, porém, se anuncia quando, por muito que se transfigure pela linguagem, a imagem ${ }^{11}$ revele restos do caos do mundo, de onde é tributária: é a demonstração de que um pouco da existência caótica não se supera, e que, dentro da linguagem, anuncia o seu "fora", sua exterioridade - essa espécie de margem informulada de sentido, que chega ao leitor como enigma.

Não descuido a minha obra. Deve-se velar por aquilo que conseguiu ascender, entre riscos e ameaças, às condições de realidade. Mas serão os meus poemas uma realidade concreta no meio das paisagens interiores e exteriores? Não possuo um só dos papeis que enchi; interessa-me a forma acabada das minhas experiências, e suas significações, mantida numa espécie de memória tensa e límpida. Os papeis, esses, estão em França (Paris ou Marselha), na Holanda e até possivelmente na África do Sul. Encontram-se nas mãos de conhecidos, desconhecidos, amigos ou inimigos - e cada qual saberá usar deles de modo particular e, suponho, exemplar. Tirarão daí indeclináveis razões para a moralidade dos seus pensamentos com relação a mim e a eles mesmos. Não, não sei de cor as pequenas composições de palavras. Retenho a fantasia, a objectividade delas -

${ }^{10}$ Mas a experiência é somente um ponto de partida, núcleo sólido e contínuo onde assenta a experiência posterior da criação. A criação é assim o encaminhamento, até consequências simbólicas extremas, de uma experiência em si própria não organizada" (HELDER, 2013, p. 137). ${ }^{11}$ Segundo Didi-Huberman (2015), a imagem contém em si uma dupla potência: quando gera conhecimento, promove uma interrupção no caos; quando gera sintoma, promove uma interrupção no saber. A alternância dessas ocorrências promove uma dialética em que a imagem aparece sempre como operadora de esclarecimento ou obscurescência. Outra forma de dizer é como faz o próprio Didi-Huberman (2016): a imagem tem uma potência efetiva (ação) e uma potência afetiva (pathos). 
ponto onde me apoio para saber que sou sólido, e tenho (ou sou) uma obra. (HELDER, 1980, p. 149)

São caras, portanto, as reflexões sobre a presença-ausente de Herberto Helder em sua própria poesia. Os seus rastros e as suas pegadas - resultantes de um processo de metamorfose pela palavra - ressurgem em forma de imagens, que, por muito que trabalhadas pela linguagem e por muito que se pretendam distantes da biografia do poeta em si, são ainda marcas de irrupção do real.

Mas o abismo (entre esse real, de que pretende se afastar o poeta, e o poema puro, como instância independente do mundo de "fora") pode ser uma armadilha engendrada por uma poética refinada e que faz caírem as interpretações que são taxativas ou 1) ao lerem a obra de Herberto Helder como uma autobiografia confessional ${ }^{12}$ ou 2) ao negarem toda e qualquer influência de sua experiência sensível em sua produção poética, como se a escrita fosse absolutamente descolada do ser-poeta. Por essa razão, cumpre-se salientar que a análise que aqui se faz sobre Herberto Helder dialoga com uma noção de entrelaçamento entre vida e obra; o poeta faz-se poema; a sua ambição é ser poema.

A presença ausente do poeta como pessoa em sua obra se relaciona à capa primeira de Photomaton $\mathcal{E}$ Vox, publicada em 1979. Esse livro, que apresenta uma espécie de rastro autobiográfico do autor, tem como imagem de capa a obra de René Magritte intitulada La réproduction interdite (1937), título que, em livre tradução, pode-se entender como "A reprodução proibida".

\footnotetext{
${ }^{12}$ Sobre a possibilidade de haver escrito uma autobiografia, Herberto Helder esclarece: "Passaram casas, cidades, mulheres - e eu sempre comovido, imagine-se, sempre percorrido pelo equívoco de uma delicadeza infernal, a espécie de delicadeza pouco óbvia com que se faz comércio com certas monstruosidades. Chego a supor que deliberei a minha biografia de trás para diante, ou escrevi torto por linhas direitas, ou estive a atirar ao alvo com a cabeça posta no alvo e o revólver apontado ao sítio fora de questão. Este interessante erro, que tanto me ocupou e tão convenientemente me desocupou, alongou-se um tempo incrível, se me inclino a contas. O meu truque foi tratar do assunto do tempo sem que eu próprio desse muito por isso, tratar que se fizesse tarde. E hoje é tarde. Tarde para mudar ou continuar. E o jardim chinês (rosas) da reforma é a oportunidade do perplexo desentendimento de tempos e tarefas - esta poda e rega, e depois a meditativa contemplação de corolas - que se infiltra na minha vida como um erro patético, uma solução docemente absurda. Nada há mais apaziguador que ter falhado em todos os lados da biografia. E - como se o não fosse: resolutamente!" (HELDER, 2013, p. 36-37).
} 


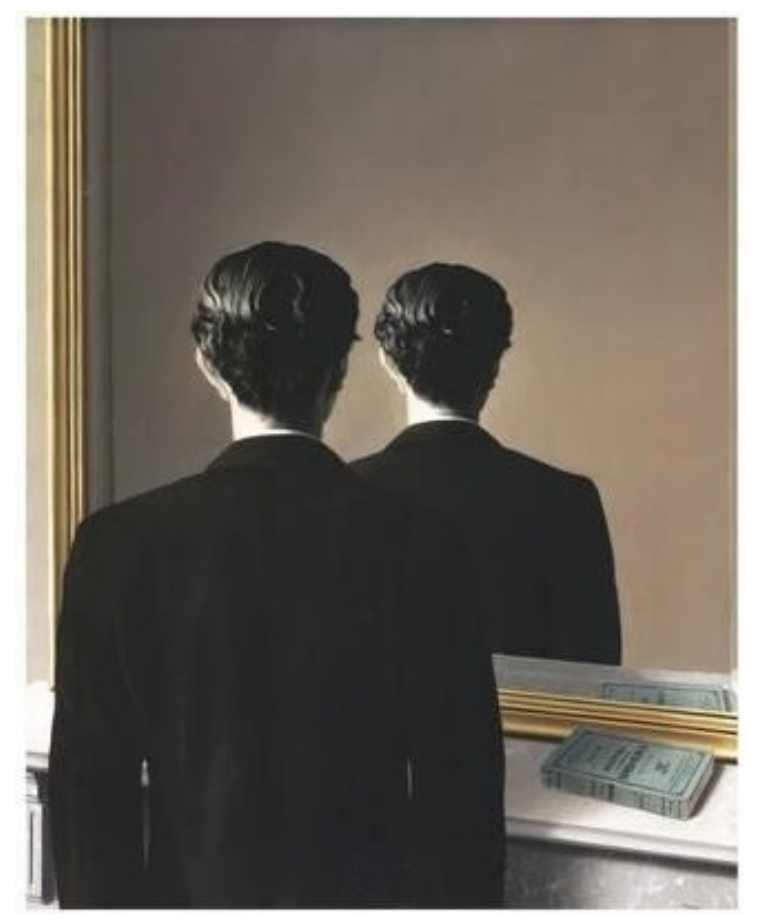

Figura 2 - René Magritte, La réproduction interdite (1937) Fonte: $<$ https://bit.ly/2sT5ELn>. Acesso em: 7 dez. 2018

A imagem apresenta um homem, que, diante de um espelho, não vê o seu reflexo, mas as suas costas; como se o olhar do espectador, que está atrás do sujeito, fosse o que gera a imagem ao espelho, e não o reflexo, como se poderia supor. Essa impossibilidade de reproduzir esse rosto do homem não inviabiliza, entretanto, a presença de uma imagem ao espelho - apenas altera o que se depreende dessa existência imagética. A tradução do nome da obra de Magritte para o inglês corrobora essa leitura: "Nottobereproduced", ou seja, "que não deve se reproduzir"; uma espécie de pacto, um combinado, para que aquilo que é a fronte do homem não se torne pública. Esse gesto surrealista de suspender a imagem que deveria aparecer, sendo o espelho um acontecimento físico objetivo, diz muito sobre a escolha para a capa de um livro que se nega inicialmente como um autorretrato, mas que é permeado pela mão de um autor que deixa rastros - o rosto não aparece, em uma recusa condizente com seu pacto de silêncio, feito onze anos antes. Mas o autor ali está. Isso se dá, sobretudo, pelo estilo.

O gesto maior de permitir que sua obra se pusesse em pé por si própria - com o mínimo de interferência ou mediação de sua vida - parece ter sido o que permitiu o estabelecimento de uma aura de poeta obscuro, que apenas existia imerso em uma névoa de mistério. Colabora com essa 
aparência, além da postura da criação solitária e silenciosa de Helder, uma recusa em ser incensado: por isso declinou de galardões e honrarias, como o Prêmio Pessoa, e os sete mil contos que o acompanhavam, em dezembro de 1994. Sobre tal negativa, indagou Clara Ferreira Alves:

Nos idos de 60, este senhor publicou Os Passos em Volta, que é uma prosa de diamante, clara e dura, eterna. E havia a poesia, ouro garimpado com esforço, separando as palavras da terra que as enlameia, da pedra que as confunde, da corrente que as arrasta. Quase ninguém tem paciência e braço para tal trabalho de homem, a tempo inteiro, mal remunerado. Como diz o António [Alçada Baptista]: "Tem um preço, ser o Herberto Helder".

Sete mil contos não chegam.

A casa é pobre, de quem cuida mais dos versos que de si mesmo. $\mathrm{O}$ monte de papéis, os livros à beira do abismo, os desenhos na parede, $\mathrm{o}$ costume. Os escritores ora são desabridos ora desarrumados. O que não são é desprendidos (ALVES, 1994, p. 10).

Em um de seus diários - o Conta-Corrente III, da Nova Série - o romancista Vergílio Ferreira reflete sobre a escrita silenciosa de Herberto Helder, após um encontro em que conversaram sobre suas produções:

Herberto é um poeta consagrado não apenas pela sua poesia, que é única, mas pela legenda que se criou à sua volta e em que ele, estrategicamente ou não, colaborou. Nada de entrevistas, nada de publicidade, nada mesmo de prémios que até fariam jeito à sua economia. Mesmo da sua biografia pouco se sabe e eu o que sei é «por ouvir dizer». Portanto longo paleio durante três horas e meia. E o que lhe pôs fim foi o meu esgotamento. Como não tinha havido convívio, falou-se de omni re scibili litteraria e arredores. Herberto sabe ouvir. E sobretudo sabe engatar no que ouve o seu entendido comentário. Porque é um poeta de uma inteligência intuitiva que não precisa muito de suporte alheio para se afirmar (FERREIRA, 1994a, p. 84-85).

O comentário de Vergílio Ferreira sobre a conversa com Herberto Helder abre uma fissura na paisagem em que o poeta estaria sempre escondido por detrás de sua obra. Ferreira diz sobre a personalidade de Helder, em "Herberto sabe ouvir". Contudo essa janela que vislumbra a pessoa misantropa é apenas uma fresta, detalhe também marcado no depoimento de Ferreira, que reflete que os dados biográficos, que sabe sobre o poeta, ouviu de outros. 
Nesse cenário de enevoamento acerca de suas condições de criação e de vida, inscrevem-se também gestos como a retirada de circulação de volumes de Apresentação do rosto, texto seu que figura como um gesto autobiográfico voluntário, bem como a quase impossibilidade de encontrar, na contemporaneidade, a obra Retrato em movimento (1967), que, a se julgar pela construção do título, apresenta minimamente uma condição biográfica, ainda que não exclusivamente. A saber: há textos de Retrato em movimento que supostamente compuseram Os passos em volta e Photomaton \& Vox. Com a multiplicidade de versões sobre a recolha de Apresentação do rosto, bem como sobre as razões para o voto de silêncio que fez, e ainda por não haver muito mais que uma autoentrevista ${ }^{13} \mathrm{em}$ matéria de comunicação com a imprensa, é espessada rigorosamente a aura que envolve tudo o que se diz sobre Herberto Helder e que não está circunscrito à sua obra ${ }^{14}$. Por essa razão, a melhor maneira de ir ao encontro de Herberto é lê-lo de-vagar ${ }^{15}$.

Em se pensando no processo criativo de Herberto Helder, o poema é lugar de rosto e voz; em Photomaton $\mathcal{E}$ Vox, o título evoca a importância da imagem e do som ("photomaton" é a cabine fotográfica que congela o momento e fornece registros instantâneos e "vox", em latim, significa "a voz"). A poética helderiana é marcada por uma ideia de transfiguração, metamorfose, fluxo contínuo. Em conteúdo, em forma ou em postura diante da poesia, Herberto Helder foi o poeta do retrato em movimento, do instável, das imagens cinematográficas. O gesto de revisão da obra corte, cesura, acréscimo, retorce, contradição, mudança sutil ou transformação absoluta - que se empenhou em fazer é atividade denunciadora dessa ideia de metamorfose:

A rigor, o trabalho realizado por $\mathrm{HH}$ com a metamorfose, na metamorfose da obra, faz dela um objeto incapturável, uma realidade

\footnotetext{
${ }^{13}$ Autoentrevista cedida ao volume 11 da revista Inimigo Rumor, em 2001. Há também algumas outras supostas entrevistas, como a que foi veiculada pela Folha de São Paulo, e teria sido concedida a João Almino, que a publicou, em 2004, sob a condição de entrevista "exclusiva e fictícia".

${ }^{14}$ Em relação às aparições públicas e à recusa da faceta pública, o ano de 2015, nos meses que antecederam a morte do poeta, foi importante: houve a publicação do livro Poemas canhotos, que contou com uma foto de rosto do autor em uma de suas primeiras páginas.

15 “Desde o poema intitulado 'Para o leitor ler de/vagar', pertencente ao conjunto 'Lugar', o poeta insiste nos sentidos da palavra de/vagar, atentando para a proximidade de valor da vagareza e da errância na leitura do poema e no exercício de uma vida 'contra o hermético/ movimento do mundo'" (ANGLADA, 2014, p. 50).
} 
que não coincide nem consigo mesma. A poesia, nesse caso, está como um centro em toda parte, uma dicção acentuada que gera energia, mas que gera também obscuridade, espraiando a dificuldade que faz seu acesso ao sentido (ANGLADA, 2018, p. 174).

Para o poeta, um poema de uma vida era o que se esperava que ele escrevesse. Por isso, houve sempre uma preocupação em nome da composição maior: o poema contínuo, aquele que não estaria nunca pronto, mas em construção, ou de/trans/formação. A imagem movente e a voz criadora são marcas dessa construção perene, que promove, em seu redor, inequivocamente a sua obscuridade constitutiva.

Mas esse poema é também o lugar onde o poeta deixa marcas de sua "alimentação". Nessa obra que se vê e que se ouve, pode-se ler:

Tudo o que disso se recolher servirá de alimentação. Quer dizer: podemos devorar a nossa biografia, podemos ser antropófagos, canibais do coração pessoal. E o escrito conservará cegamente um tremor central, esse calafrio de ter olhado alguma vez o nosso rosto filmado no abismo do mundo (HELDER, 2013, p. 29).

A alimentação helderiana, contudo, não consiste apenas em devorar a sua própria biografia. A hipótese de poesia "onívora" - termo cunhado e explicado por Helena Carvalhão Buescu em artigo intitulado "Herberto Helder: uma ideia de poesia omnívora" (2009) - tem como eixo central a noção de que o poeta desenvolve uma "alimentação" de outras existências poéticas sem um aparente critério preestabelecido. Em outras palavras, a criação de Herberto Helder transitaria sob diferentes vias de contaminação, em que reverberariam vozes ouvidas com o crivo da atenção. A sua prática de tradução - a que o próprio poeta chamou de "mudança para o português" - é um exemplo dessa fagia cujos critérios não são mais que as preferências éticas ou estéticas do autor ${ }^{16}$. Sobre essa metodologia de tradução que pressupõe uma mudança, escreve Helder:

\footnotetext{
${ }^{16}$ Os principais livros de poemas "mudados" de Herberto Helder são: O bebedor nocturno (1968), Ouolof: poemas mudados para o português (1997), Poemas ameríndios (1997) e Doze nós numa corda: poemas mudados para o português (1997). Todos sinalizam em seus nomes uma ideia de liberdade, ainda que erigidos sob a égide da influência ou da filiação.
} 
Uma pessoa pergunta: e a fidelidade? É que procuro construir o poema português pelo sentido emocional, mental, linguístico que eu tinha, sub-repticiamente, ao lê-lo em inglês, francês, italiano ou espanhol. É bizarramente pessoal. Mas não há fidelidade que não seja. Senão, claro, a ainda mais bizarra fidelidade gramatical que, de tão neutra, não pode ser fidelidade. Alain Bosquet prevenia algures as pessoas contra essa espécie de fidelidade. Não levantava, ele, sérias reservas ao facto de se traduzir um poema húngaro desconhecendo o húngaro, e dizia: façase um poema francês (dirigia-se aos poetas franceses). Porque Bosquet só admitia que fossem poetas a praticar a versão de poesia. Um bom aliado, este Alain.

E agora que já disse tudo, digo que não gosto de justificações. A regra de ouro é: liberdade. E pede-se desenvoltamente ao leitor: que leia aqueles poemas o mais livremente que puder. (HELDER, 2013, p. 69)

Diante dessa formulação de fidelidade a um texto a partir da liberdade de reconstruí-lo, Helder se aventurou na poesia esquimó, na dos peles-vermelhas, dos indonésios, em passagens bíblicas, na tradição órfica: como um baobá, que, no prefácio de Edoi lelia doura: Antologia das vozes comunicantes da poesia moderna portuguesa, ilustra sua ideia de "árvore carnívora", que devora nomes e assim os transforma em matéria orgânica, alimento:

Eu podia contar gemeamente duas histórias: uma afro-carnívora, simbólica, a outra silenciosa, subtil, japonesa. De cada uma delas acabariam por decorrer um tom e um tema. A história carnívora foi colhida algures, de leitura, e respeita a uma tribo que sepultava os seus mortos no côncavo de grandes árvores. As árvores, a que tinham dado o nome do povo: baobab, devoravam os cadáveres, deles iam urdindo a sua própria carne natural. Pelo nome tirado de si e posto na alquimia, a tribo investia-se nas transmutações gerais: a morte levava o nome, e o nome, activo e tangível, crescia na terra. Emocionavam-me a fome botânica e o triunfo das copas, o empenho tribalmente mágico, regrado pelo insondável entendimento das metamorfoses da carne no esquema orgânico da matéria. E apanho aqui o símbolo, como se intelege neste livro: uma imagem de si mesma, uma imagem absoluta, universal, devora esta gente, e esta gente põe a assinatura na imagem devolvida ao mundo. É quase tudo quanto há para dizer no plano prático da poesia. (...) Neste sistema de vozes não deixa a natureza que entrem outros veios: é uma clepsidra para ajuste de certas horas, porventura nocturnas, marcante a dominação e os passos de um sol negro magnificante. Fique indiscutível que é uma antologia de teor e amor, unívoca na multiplicidade vocal, e ferozmente parcialíssima. Quando 
os lemos lado a lado, a todos estes poetas e poemas, sabemos estarem eles entregues ao serviço de uma inspiração comum, a uma comum arte do fogo e da noite, ao mesmo patrocínio constelar. O que varia é a política das formas, maneira de guerra e hipnotismo das pessoas e dos tempos. Nunca o estilo de alimento, de morte, de mudança. Nada disto aclara, nada pretende: ache cada um a sua árvore vorazmente nupcial, sem inquirir de um silêncio que só responderá mostrando o absurdo no absurdo, aludindo com a técnica oblíqua de um exemplo qualquer à qualidade da acção, mesmo que a acção, no domínio dos silêncios, seja verbal. Ache, na sua própria cegueira, a vista de uma paisagem transfigurada: a vida começa a ser real. Algures, aqui. (HELDER, 1985, p. 7-8)

A compreensão da metamorfose da carne como esquema orgânico da natureza elabora um norte que segue o poeta na construção de sua obra: é o que aponta, quando mostra a existência das árvores carnívoras como alegorias da poesia - "é quase tudo quanto há para dizer no plano prático da poesia". Essa imagem, utilizada no prefácio da antologia da poesia moderna portuguesa, parece ser um convite a pensar na elaboração de um panteão que não cede a noções como hierarquia ou cânone, pois, para Herberto Helder, essa árvore comedora - esse gesto de se alimentar da carne para retorná-la ao mundo - não fornece respostas, mas apenas apresenta o que há de absurdo ao se tentar compreender o que não passa de um exercício subjetivo de escolha. A eleição de poetas e poemas que compõem uma antologia, para Herberto Helder antologista, é uma ação que o leitor pode copiar, aos moldes de um casamento: para cada leitor, um amor - sua árvore vorazmente nupcial. Ou ainda: para cada cegueira, uma visão: tão somente construída pela capacidade do imaginar.

Ao se alimentar das carnes humanas, a árvore absorve os corpos que outrora compunham aquela tribo que recebeu o nome da árvore. A nomeação de um povo segundo o nome de um vegetal é um elemento de reversibilidade potente por si só: é a natureza nomeando Orfeu. Mas o processo se torna ainda mais complexo e completo com a percepção que a tribo nomeada pelas árvores é por elas engolida.

A árvore carnívora, que é Herberto Helder, devora os poetas e poemas que elenca em sua antologia, mas explica a razão de tê-los elegido tão somente pela força do desejar: é uma escolha parcialíssima, sem qualquer pretensão de ocultar a subjetividade do que é antes de tudo: um leitor. Nesse sentido, todos os antologizados estariam sob uma mesma 
abóboda, dispostos a uma mesma arte do fogo, com as ressalvas das peculiaridades motivadas pela forma apresentada por cada um. Esse exercício de recolha das afinidades, quase uma sugestão ao leitor da antologia, é, segundo o que se coloca no encerramento do prefácio, aquilo que provoca uma irrupção de realidade. A capacidade de imaginar uma paisagem e assim enxergar a despeito de toda cegueira é o prodígio da metamorfose, que tudo celebra no devir: é como amar aquilo que ainda não é - e que permanece como promessa eternamente inconclusa.

De tal maneira, o homem volta a criar a Natureza, que antes o criou; é a relação da tribo com o baobá. O poeta que cria a sua obra, que o cria em seguida: o oroboro $^{17}$ é a alegoria que pode melhor explicar essa retroalimentação cíclica e sem começo, nem final.

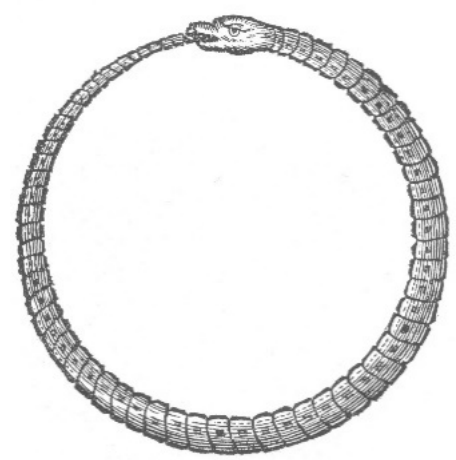

Figura 3 - Oroboro

Fonte: <https://bit.ly/2Frfiey>. Acesso em: 2 jan. 2019

A ideia de transmutação, de alimentação e de metamorfose, que advém dessa hipótese "onívora", relaciona-se à capa primeira da súmula Ou o poema contínuo. A obra escolhida para ilustrar tal volume é a de Saturno devorando a su hijo, de 1819, do pintor espanhol Francisco de Goya ${ }^{18}$.

\footnotetext{
${ }_{17}$ Oroboro vem do grego antigo: oủoú significa "cauda" e ßó@os, que significa "devora". Assim, a palavra designa "aquele que devora a própria cauda"; é também figura simbólica no campo da alquimia, que parece dizer que o fim é o começo.

${ }^{18}$ Francisco de Goya (1746-1828) foi uma grande expressão do Romantismo. Em seus últimos anos, explorou temas sombrios nas "Pinturas Negras", com técnica grotesca e forte. A referida pintura apresenta Saturno (deus do tempo) devorando seu filho para que ele não tome seu lugar divino.
} 


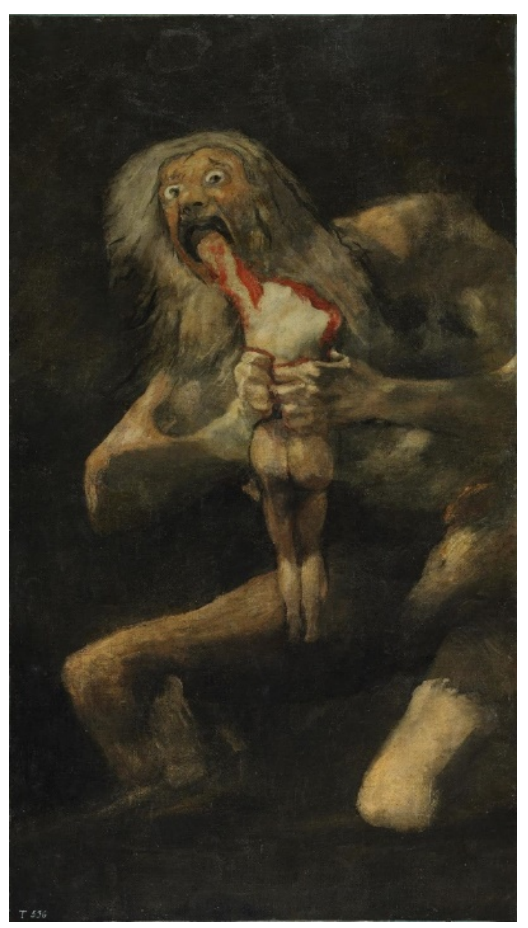

Figura 4 - Francisco de Goya, Saturno devorando a su hijo (1819-1823)

Fonte: <https://bit.ly/2lyMMKL>. Acesso em: 7 dez. 2018

Em um gesto de correspondência, seria possível inferir que Saturno ilustraria o poeta, que devoraria sua obra, sua cria. Em sentido contrário, pode-se pensar em Saturno como a obra, que se torna a criadora do poeta, e o devora. Sobre tal hipótese, escreve Luis Maffei:

A igualdade por mim referida há pouco [de que a conjunção "ou" em Ou o poema contínuo é marca de igualdade entre o nome do autor e a sua obra; Herberto Helder = poema contínuo], assinalo, é sugerida já na capa do volume: a obra é Saturno, a obra pode ser equivalida não apenas a uma divindade, mas também ao próprio tempo, pois se mantém no tempo enquanto o mesmo tempo, saturnianamente legível, devora o autor, devora o indivíduo (MAFFEI, 2006, p. 169-180).

Essa possibilidade está descrita em uma afirmação de Martelo, no texto "Assassinato e assinatura" (2010), de que o poema escreve o poeta, e de que o poeta é repetidamente assassinado pela escrita. Nessa perspectiva, a obra, não só devoradora e criadora do poeta, é também análoga ao tempo, que tudo cria e que da sua criação se despede por meio de um banquete carnal. De tal maneira, o baobá anteriormente referido seria uma espécie de alegoria não só do poeta, em sua escolha heterofágica, 
mas de toda a sua obra, que a ele se iguala pela conjunção "ou", e que apresenta em si as marcas da devoração, ou, como afirma Blaise Cendrars, citado pelo próprio Herberto Helder: "et lemétier d'homme de guerre est une choseabominable et pleine de cicatrices, commelapoésie" (HELDER, 2013, p. 61). Essa maneira singularíssima de eleger sua rede de vozes comunicantes ${ }^{19}$ esse mapa de influências horizontais e carnívoras - também aponta para a elaboração da figura mítica do poeta, cujo rosto que apresenta pelos poemas está desfocado e cuja voz, que se dá a ouvir, está distante e distorcida pelo mistério.

As escolhas (de estilo e de conteúdo) helderianas soam muito particulares: a (de)composição imagética, esse quadro de perdas - ou de evanescências -, se anuncia em parte por escolhas sintáticas e de pontuação absolutamente singulares, evidência de unicidade de sua obra. Como refletido a partir do conto em que o poeta reflete sobre o "como escrever", o estilo seria uma sintaxe própria, que anunciaria sua forma particular de se ligar ao mundo - afetando-o e se deixando por ele afetar. Nesse sentido, escrever com seu estilo próprio (com sua sintaxe particular) seria uma forma de equilibrar o gesto de escrever as imagens e de por elas ser escrito.

A pontuação, essa "caixa de velocidades", é marca de como o transitar entre espaço e tempo é maleável e repleto de vaivém - o que indica a necessidade de problematização da(s) forma(s) quando se estuda a poética helderiana, pois "tudo isso instiga à percepção do ritmo" (HELDER, 2013, p. 143). A linguagem com que Helder (se) escreve inaugura uma gramática muito singular, uma "gramática profunda" (HELDER, 1998). Toda a sintaxe é transferida para um plano em que mais importam o ritmo e as imagens, sendo assim remodelada. Regido pela máxima "liberdades, liberdade" (HELDER, 2014, p. 224), o poeta põe-se a serviço de uma força maior: a própria poesia. A criação - e a resistência aos

\footnotetext{
${ }^{19}$ A sonoridade de "vozes comunicantes" parece remeter a' Os vasos comunicantes (1932), de André Breton, obra em que o surrealista divide em "vasos" diferentes aquilo que é pensado e aquilo que é sonhado - uma espécie de leitura freudiana do pensado (consciente) e do onírico (pelas vias do inconsciente). Porém, com o modelo exemplar emprestado da Física dos fluidos, Breton demonstra como esses vasos estão interligados e apresentam sempre a mesma quantidade de líquido, o que pressupõe certo equilíbrio entre o sonho e a vigília. A possível aproximação com a reunião de Helder (Edoi Lelia Doura) se relaciona, para além da sonoridade aproximada, com a aproximação entre as escolhas conscientes e inconscientes das vozes comunicantes eleitas para a antologia - espaço de transmutação, solubilidade e comunicação entre "vasos" supostamente isolados.
} 
discursos óbvios dominantes - mostra-se, assim, como traço de experimentação, de vanguarda permanente.

Em relação à postura vanguardista, ressalta-se o breve contato de Herberto Helder com o Surrealismo português - o que posteriormente é negado em termos estéticos pelo próprio poeta. Mas um dos motivos dessa separação antecede a sua negação. A geração vinculada ao Surrealismo frequentada por Helder foi a segunda, que, como pontua Izabela Leal (2008), por razões calcadas na política do país, e por uma espécie de radicalização em relação à geração de Cesariny (a primeira surrealista), distancia-se em forma e em conteúdo da sua antecessora. A geração que se reunia no Café Gelo (António José Forte, Manuel de Lima, Ernesto Sampaio, Raul Leal, João Rodrigues, Helder Macedo, Manuel de Castro e, naturalmente, Herberto Helder) passou à História, mais que como Surrealistas, como Abjeccionistas. Segundo Leal, nesse sentido, a geração abjeccionista é a que considera que

a poesia [...] é também uma forma de estar só, e é nessa solidão que o fazer poético ultrapassa o próprio texto, transformando o ato de escrita num ato não puramente estético [como o era o Surrealismo], mas também ético e político. Tal ato inscreverá novamente, como em Camões, a questão da experiência dentro do âmbito literário (LEAL, 2008, p. 56).

A recusa helderiana ao Surrealismo, exposta na fala que faz em sua autoentrevista, apenas confirma esse distanciamento, ainda que nem aos Abjeccionistas este poeta vá se vincular posteriormente. Para Herberto Helder, "O surrealismo foi um equívoco, uma soma de equívocos" (HELDER, 1990, p. 30). Em Photomaton \& Vox, escreve, com grande sarcasmo:

Olhem: não, obrigado. Vou dizer-lhes: vai ser escada para subir e depois a gente ficará lá em cima experimentando o transe do silêncio. Os senhores não percebem nada de destruições. Temos de aturar todo o aborrecimento de uma velha modernidade: Fernandos Pessoas, surrealismos, a política com metonímias, a filosofia rítmica, as religiosidades heréticas, as pequenas tradições de certas liberdades. Acabou-se.

(O verbo impregnava a terra, a energia impregnava a terra).

Tudo isto é para a grande máquina circulatória, o aparelho digestivo, o sistema respiratório. Coisas do corpo que precisa de transe, êxtase. 
Essa é a significação. Estamos a trabalhar com instrumentos que abalam tudo. Há uma energia geral comutada à passagem pelo corpo. É uma comutação cultural. E afastem daqui o surrealismo. Afastem a metafísica, a política, as ideiazinhas de merda. Um transe. A palavra é uma provocação destinada a uma espécie de intransigência física. $\mathrm{E}$ que é o corpo senão ele mesmo?

Os poetas estão a avançar com uns vagares de galinholas. Porra. (HELDER, 2013, p. 117-118).

Esse distanciamento dos surrealistas portugueses foi percebido sincronicamente à sua produção. Vergílio Ferreira escreve em seus diários, sobre um encontro que tem com o poeta:

Eu disse-lhe que uma coisa que muito me agrada na sua poesia é a gravidade. A poesia dele é feita de explosões metafóricas de arrebatamento em que é difícil descobrir o fio condutor, fixar a linha contínua que deve orientá-las. Mas basta a surpresa das suas associações para já nos sentirmos dentro do poema. Quando lhe anotei a sua gravidade, ousei contrapô-la a uma certa palhacice do nosso papa surrealista [Mário Cesariny]. Herberto não concordou. Mas eu lembrei-lhe o espalhafato com que ele continua a palhaçar em provocação de certas fotografias que já fazem dó. E ele aí calou-se (FERREIRA, 1994b, p. 163-164).

Já apontadas as diferenças, a respeito do que é comum a Herberto Helder e ao Surrealismo português, salienta-se a percepção da impossibilidade de representação do real - ou uma "desconfiança básica diante do real" (DAL FARRA, 2000, p. 150) - o que parece ser elemento impulsionador (mas não exclusivo) para a composição de seu modo peculiar de fazer poesia, em que assume uma postura demiúrgica:

Seu milagre é o de - por entre a sombria e fulgurante guerra de imagens, símbolos, metáforas, contradições, alegorias, alusões, obliquidades, descontínuos, incompletudes, sobrecarregamentos, etc. - arrancar da matéria residual inativa (que é o mundo) a raiz ainda viva de cada coisa, de modo a ceder ao espírito a recuperação dos esquecidos vasos energéticos que nunca deixaram de estar unidos à mesma matéria (DAL FARRA, 2000, p. 150).

A esse "milagre" operado pela transposição da matéria real, do mundo, à matéria do poema, podem-se associar características como: o 
gesto de "cantar" como criador de mundos; a voz soberba e potente, que é capaz de penetrar nas leis da Natureza e regê-las, e ser por ela influenciado; o uso das palavras como inventoras de realidades; dentre outras. O uso de elementos primários é, na poética helderiana, também marca de uma filiação à Natureza, ainda que pelo gesto de sua transfiguração. Não é raro encontrar, no longo poema contínuo de Herberto Helder, os nomes "mãe", "fruto", "água", "fogo", "sol", "leite", "criança"20, e outros que desses derivam; palavras que se repetem e que inauguram esferas de sentido recorrentes, a que se pode chamar de nós temáticos. Podem-se sinalizar como nós temáticos aquelas imagens que, mesmo evanescentes, deixam um rastro fantasmagórico, e assim apontam para uma recorrência - tão fugidia como só pode haver em uma obra que preza primordialmente pela ideia de metamorfose. Em passagens de seu vasto poema contínuo, Helder convida o leitor a visitar essas reincidências.

Nessa apresentação do rosto, vários dos temas sinalizados funcionam como reencenação do passado, e, para além disto, como personagens vivos, complexos e vibrantes, e a rememoração está colada ao fazer poético. O incômodo da memória com a tentativa da lembrança e o estremecimento do esquecimento talvez sejam o objeto fundador desta poética, em que Helder aponta como o poema é a assimilação concreta de um tempo perdido.

Os nós temáticos já citados remontam à ideia de que o que irrompe na poesia traz algo do caos do mundo para desaguar na suposta ordem da linguagem. Por isso, as reflexões sobre a participação biográfica de Herberto Helder em sua poesia, sua maneira carnívora de se relacionar com sua rede de "vozes comunicantes" e sua condição de obscuridade como inventor de um mundo poético são potentes: os nomes das coisas apontam no mundo um aspecto de realidade, de materialidade e de solidez, e é necessário que se apreenda - ou que se vislumbre, em meio à névoa mutante da criação helderiana - qual o trajeto entre as coisas-em-si e suas imagens frequentes, transfiguradas e metamórficas, apresentadas por Herberto Helder ao longo de seu poema contínuo.

\footnotetext{
${ }^{20}$ Recorrências apontadas por Rui Alberto Costa, em seu ensaio "A permanência de Orfeu na literatura contemporânea: o espaço órfico em Herberto Helder" (2010).
} 


\section{REFERÊNCIAS}

ALVES, Clara Ferreira. Louvor e simplificação de Herberto Helder. Revista Expresso, p. 10, 17 dez. 1994. Disponível em:

$<$ http://www.citi.pt/cultura/literatura/poesia/helder/nao_nin.html>.

Acesso em: 19 fev. 2018.

ANGLADA, Carolina. O poema é um animal: obscuros bestiários de Herberto Helder. 2014. 129 f. Dissertação (Mestrado em Estudos Literários) Faculdade de Letras, Universidade Federal de Minas Gerais, Belo Horizonte, 2014.

BAPTISTA, Abel Barros. A formação do nome: duas interrogações sobre Machado de Assis. Campinas: Editora Unicamp, 2003.

BEAUJOUR, Michel. Miroirs d'encre: rhétorique de l'autoportrait. Paris: Éditions du Seuil, 1980.

BENJAMIN, Walter. Infância em Berlim. In Rua de mão única. Tradução de Rubens Rodrigues Torres Filho e José Carlos Martins Barbosa. 3. ed. São Paulo: Brasiliense, 1987. p. 71-142. (Obras Escolhidas II).

BRAZ, Paulo. O que vemos, ao ler Herberto Helder: algumas notas. Revista da Rede Internacional Lyracompoetics, v. 6, no 10, p. 71-89, 2015.

BUESCU, Helena Carvalhão. Herberto Helder: uma ideia de poesia omnívora. Diacrítica, v. 23, nº 3, 2009, p. 49-63. Disponível em:

$<$ http://ceh.ilch.uminho.pt/publicacoes/Diacr\%C3\%ADtica_23-3.pdf $>$. Acesso em: 7 dez. 2018.

DAL FARRA, Maria Lúcia. Posfácio. In HELDER, Herberto. O corpo o luxo a obra. São Paulo: Iluminuras, 2000. p. 149-157.

DIDI-HUBERMAN, Georges. A imagem queima. In Falenas: ensaios sobre a aparição, 2. Lisboa: KKYM, 2015.

DIDI-HUBERMAN, Georges. Que emoção! Que emoção? São Paulo: Editora 34, 2016.

FERREIRA, Vergílio. Conta corrente: nova série III. Lisboa: Bertrand, 1994a.

FERREIRA, Vergílio. Conta corrente: nova série IV. Lisboa: Bertrand, 1994b.

GUEDES, Maria Estela. A obra ao rubro de Herberto Helder. São Paulo: Escrituras, 2010. 
GUEDES, Maria Estela. Herberto Helder: poeta obscuro. Lisboa: Moraes Editores, 1979.

GUSMÃO, Manuel. Anonimato ou alterização. SemeaR, nº 4, 1998.

HELDER, Herberto. Apresentação do rosto. Lisboa: Ulisseia, 1968.

HELDER, Herberto. As turvações da inocência. Luzes da Galiza, 4 dez. 1990. Disponível em: <https://www.publico.pt/2015/03/24/ficheiro/as-turvacoesda-inocencia-20150324-170603>. Acesso em: 7 dez. 2018.

HELDER, Herberto. Cinemas. Revista Relâmpago, Lisboa, no 3, p. 7-8, 1998. HELDER, Herberto. Doze nós numa corda. Lisboa: Assírio \& Alvim, 1997a.

HELDER, Herberto. Edoi lelia doura: antologia das vozes comunicantes da poesia moderna portuguesa. Lisboa: Assírio \& Alvim, 1985.

HELDER, Herberto. Em minúsculas. Porto: Porto Editora, 2018.

HELDER, Herberto. Entrevista. Inimigo Rumor, Rio de Janeiro: 7 Letras, $\mathrm{n}^{\underline{0}}$ 11, 2º sem. 2001.

HELDER, Herberto. Exclusivo e fictício: uma forma recortada do mundo. Folha de S.Paulo, São Paulo, 25 abr. 2004. Entrevista concedida a João Almino. Disponível em:

<https://www1.folha.uol.com.br/fsp/mais/fs2504200412.htm>. Acesso em: 7 dez. 2018.

HELDER, Herberto. Letra aberta. Porto: Porto Editora, 2016a.

HELDER, Herberto. O corpo o luxo a obra. São Paulo: Iluminuras, 2000.

HELDER, Herberto. Os passos em volta. Lisboa: Assírio \& Alvim, 1980.

HELDER, Herberto. Os passos em volta. Rio de Janeiro: Tinta-da-China Brasil, 2016b.

HELDER, Herberto. Ou o poema contínuo. São Paulo: A Girafa Editora, 2006.

HELDER, Herberto. Ouolof. Lisboa: Assírio \& Alvim, $1997 \mathrm{~b}$.

HELDER, Herberto. Photomaton E Vox. Porto: Assírio \& Alvim, 2013.

HELDER, Herberto. Poemas ameríndios. Assírio \& Alvim, 1997c.

HELDER, Herberto. Poemas canhotos. Porto: Porto Editora, 2015.

HELDER, Herberto. Poemas completos. Porto: Porto Editora, 2014. 
LEAL, Izabela. Doze nós num poema: Herberto Helder e as vozes comunicantes. 2008. 152 f. Tese (Doutorado em Letras Vernáculas) - Faculdade de Letras, Universidade Federal do Rio de Janeiro, Rio de Janeiro, 2008.

MAFFEI, Luis. Do mundo de Herberto Helder. Rio de Janeiro: Oficina Raquel, 2017.

MAFFEI, Luis. Herberto Helder, sim, o poema contínuo. Diadorim, v. 1, p. 169-180, 2006. Disponível em:

$<$ https://revistas.ufrj.br/index.php/diadorim/article/view/3844>. Acesso em: 7 dez. 2018.

MARINHO, Maria de Fátima. Herberto Helder: a obra e o homem. Lisboa: Arcádia, 1982.

MARTELO, Rosa Maria. Assassinato e assinatura. In A forma informe: leituras de poesia. Lisboa: Assírio \& Alvim, 2010. p. 83-111.

MARTELO, Rosa Maria. O nome da obra: Herberto Helder ou o poema contínuo. Lisboa: Documenta, 2016.

Recebido em 04 de junho de 2020

Aprovado em 30 de outubro de 2020

Licença: (ㄷ) (i) (요

Constance von Krüger de Alcântara e Silva

Doutoranda em Teoria da Literatura pelo Programa de Pós-Graduação em Estudos Literários da Universidade Federal de Minas Gerais, Brasil.

Contato: tance_k@hotmail.com

(D): https://orcid.org/0000-0001-6202-5084 